\title{
REGULATORY CAPITAL IS A PANACEA FOR EFFICIENCY, CREDIT GROWTH AND REDUCING NON-PERFORMING LOANS IN COMMERCIAL BANKS
}

\author{
Amina Malik', Babar Zaheer Butt ${ }^{2 *}$, \\ Shahab Ud Din ${ }^{3}$ and Haroon Aziz ${ }^{4}$ \\ ${ }^{1}$ Department of Management Sciences, \\ COMSATS University Islamabad, Wah Campus, Pakistan \\ ${ }^{2}$ Tohoku University of Community Service \& Science, Japan \\ ${ }^{3}$ Karakoram International University Gilgit-Baltistan, Ghizer Campus, Pakistan \\ ${ }^{4}$ All Pakistan Textile Manufacturing Association, Pakistan
}

\begin{abstract}
This study examined the effectiveness of regulatory capital in enhancing efficiency and credit growth and reducing bad loans in commercial banks listed on the Pakistan Stock Exchange (PSX) from 2010 to 2019. Precisely, the impact of capital adequacy ratio (CAR) was studied on net interest margin (NIM), credit growth (CR) and non-performing loans (NPLs). The impact of capital adequacy regulations was assessed by retrieving data from financial statements analysis (FSA), Bank Financial statements and the World Bank website. Panel regression models including ordinary least squares (OLS), fixed and random effects under robust title were applied in this study. Results revealed that the implementation of stringent CAR plays the role of panacea and increases interest margin \& credit growth and a reduction of NPL in Pakistani commercial banks. The study provides practical results for regulators to customize regulations on credit growth to reduce non-performing loans and maintain healthy growth of loans by not compromising on interest margins as well as maintenance of minimum capital adequacy ratios. With the high significance of stringent minimum capital adequacy for banks, the findings of the study are valuable for regulators, banks, auditors and investors, as capital adequacy ratio commonly plays the role of Panacea in terms of efficiency, credit growth and reduction in non-performing loans.
\end{abstract}

Keywords: capital adequacy ratio, efficiency, credit growth, non-performing loans

ARTICLE INFO

Article History:

Received: 14 February 2021

Accepted: 11 June 2021

Published: 31 August 2021

* Corresponding Author: Babar Zaheer Butt. E-mail: babarzb@gmail.com 


\section{INTRODUCTION}

After the onset of global financial distress, an eminent need was felt for the protection of financial institutions against distress and bankruptcy. High leverage and liquidity crunch and poor risk management resulted in the formation of Basel Accords to strengthen the capital framework. Therefore, the minimum capital requirements are certainly quite important. Excessively strict capital adequacy ratios also have their consequences on efficiency and credit growth as well as bad loans (Hafez, 2018).

A certain amount of minimum capital is maintained as required by the regulators and is termed as Capital adequacy, which gives coverage against uninsured and unsecured risks that convert into losses. 1 The State Bank of Pakistan implemented Basel I in 1997 to mitigate bank credit risks. Later on, Basel I was modified and it included market risk-weighted assets as well. Further, Basel II was implemented by the State Bank of Pakistan in 2008, in which the Capital Adequacy Ratio (CAR) was calculated against credit, market, as well as operational risks in Pillar 1 and the rest of the risks, were included in Pillar II. Lastly, the State Bank of Pakistan implemented Basel III in a phased manner from 2013 till 2019, which included the CAR2. Therefore, capital plays a pivotal role in determining the activities of the banks as well as a buffer against unexpected losses (Karim et al., 2014).

Banks with insufficient capital have more chances of insolvency than a sufficiently well-capitalized one. Likewise, earlier literature also revealed that well-capitalized banks are more efficient as compared to banks with less capital (Kwan \& Eisenbeis, 1997). Capital is an important ingredient for credit growth and improving net interest margins which ultimately improves efficiency and reduces bad loans when properly utilized. This research sought to check whether the theoretical importance of capital adequacy ratio has practical benefits for the commercial banking sector and the economy as well. The objective of this research study was to assess whether there is a positive impact of regulatory capital requirements imposed by regulators on efficiency in terms of improvement in net interest margin of commercial banks in Pakistan. Secondly, this research also assessed whether regulatory capital had resulted in improvement in credit growth in banks. Thirdly, the

1 Regulatory capital and its functions, Retrieved from https://www.sbp.org.pk/BS/Bai.asp

2 Implementation of Basel Capital Framework in Pakistan, retrieved from https://www.sbp.org.pk/ BS/Bai.asp 
study also evaluated whether regulatory capital has reduced bad loans in Pakistani commercial banks.

This paper uniquely contributes to the existing line of research in numerous ways. Firstly, earlier studies have focused on the relationship between capital adequacy and financial stability (Waqas \& Bahrain, 2019), capital adequacy and profitability (Haris et al., 2020), factors affecting the performance of banks (Gul et al., 2011), capital adequacy and liquidity (Rafique, Toor, \& Bashir 2020). Unlike the empirical literature, this study explicitly and collectively focussed on the impact of regulatory capital adequacy requirement on efficiency, credit allocation and non-performing loans in the Pakistani context. More precisely, this study also focussed on the impact of the imposition of regulatory capital requirement on risk-taking behavior, credit supply and interest rate spread. Secondly, this study also focussed on the interrelationship between efficiency, credit allocation and non-performing loans as well as macroeconomic variables. Thirdly, the versatility in the banking sector and the regulations paradigm has prompted the investigation regarding its impact on efficiency, credit growth and nonperforming loans and other control variables including fees and industry variables like GDP. Lastly, this research also provides imminent findings for regulators who can play a significant role in customizing regulations while keeping in view the actual position.

The rest of the paper is organized as follows. Section 2 describes the literature review and hypotheses development. Section 3 presents the research design and sample selection which includes sample selection and data, model specification and variables and estimation strategy. Empirical results are discussed in Section 4. Section 5 concludes the study.

\section{LITERATURE REVIEW AND HYPOTHESES DEVELOPMENT}

\section{Regulatory Capital and Efficiency}

Capital adequacy ratio plays the role of safety valves and circuit breakers for regulators as well as for the stakeholders to mitigate the risks of the banks. The application of these rules helps in achieving governance 
(El-Ansary \& Hafez, 2015). Abbas et al. (2019) investigated the impact of capital, tier and equity capital buffer on risk and net interest margin and found that interest is relatively lower in pre-crisis than during crises periods which shows that impact of capital buffer on net interest margin varies in different periods. Whereas, on the other side, earlier literature reveals that well-capitalized banks are more efficient as compared to banks with less capital (Kwan \& Eisenbeis, 1997).

Earlier literature also showed that stricter capital requirements improve the cost as well as bank efficiency (Pasiouras et al., 2009). In this respect, Osei-Assibey and Asenso (2015) found a positive relationship between minimum capital ratio and net interest margin in commercial banks by using panel data from the year 2002 to 2012 in Ghana. Moreover, Cruz-García et al. (2020) also found a positive relationship between capital stringency and net interest margin by using panel data for OECD countries for the year 2000 to 2014. In view of, the above literature, we developed the following testable hypothesis:

H1: There is a positive relationship between capital adequacy ratio and net interest margin.

\section{Regulatory Capital and Credit Growth}

Global financial crises and the massive credit growth led to the building up of systematic risks and ultimately to financial instability. One of the underlying causes of the financial crisis was the credit boom. Therefore, a regulatory framework was devised by implementing minimum regulatory capital requirements in the shape of Basel Accords. Likewise, minimum capital requirements are extremely essential, whereas, overly stringent capital adequacy requirements can also hamper credit expansion (Osei-Assibey \& Asenso, 2015). Karim et al. (2014) conducted a study in 14 organizations of Islamic Conference (OIC) countries from the year 1999 to 2009 and found a positive relationship between capital adequacy requirements and loan growth in Islamic and conventional banks.

In this respect, a recent study on the relationship between capital adequacy ratio and credit growth in Vietnamese banks during the year 2010 to 2017 have revealed a positive relationship among them (Dao \& Nguyen, 
2020). Moreover, Osei-Assibey and Asenso (2015) also observed a positive relationship between capital adequacy ratio and credit growth. Based on the results of Osei-Assibey and Asenso (2015) and Dao and Nguyen (2020), we developed the following testable hypothesis:

H2: There is a positive relationship between capital adequacy ratio and credit growth.

\section{Regulatory Capital and Non-Performing Loans}

Non-performing loans are the major hindrance to the growth and development of the banking sector (Zhang et al., 2016). Therefore, regulatory interventions in the shape of minimum capital adequacy requirements and non-performing loans have a relationship. Capital serves as a buffer to mitigate risks (Alexandri \& Santoso, 2015). Moreover, better supervision also plays a positive role by restricting unsafe and unsound lending activities (Kupiec et al., 2017). Some of the earlier researchers have used panel data analysis to study the relationship between bank capital and lending (Bernanke et al., 1991; Cornett et al., 2011).

Carlson et al. (2013) also observed that well-capitalized banks have relatively stronger loan growth. In this respect, Yulianti et al. (2018) conducted a study on the relationship between capital adequacy ratio effect non-performing loans in public banks of Indonesia for the year 2012 to 2016 and found a positive impact of capital adequacy ratio on non-performing loans. Likewise, Abiodun et al. (2020) carried out a study in Nigerian banks of ten leading banks from 2007 to 2017 and found that non-performing loans are negatively related to capital adequacy. Based on the results of Abiodun et al. (2020) and Yulianti et al. (2018), we suggested the following hypothesis:

H3: There is a negative relationship between capital adequacy ratio and non-performing loans. 


\section{RESEARCH METHOD}

\section{Sample Selection and Data}

This research used a sample of twenty-one commercial banks listed on the Pakistan Stock exchange (PSX) from the year 2010 to 2019. The sample included public and private banks. Banks-specific variables data was retrieved from the financial statement analysis (FSA) published by the State Bank of Pakistan (SBP) for the period 2010-2019. It is a comprehensive and reliable data source, which provides consolidated information on the financial sector of the country. Furthermore, the data on capital adequacy ratio was hand collected from the annual reports of the sample banks. Whereas, data on the Gross domestic product (GDP) was taken from the World Bank Website ${ }^{4}$. Policy rate data was retrieved from the country economy website. ${ }^{5}$

\section{Econometric Model Specification and Variables}

To study the impact of regulatory capital on efficiency, credit and non-performing loans in commercial banks of Pakistan we modeled three separate equations specified below:

$$
\begin{aligned}
& N I M_{i t}=\beta_{0}+\beta_{1} C A R_{i t}+\beta_{2} B P R_{i t}+\beta_{3} C R_{i t}+\beta_{4} F E E S_{i t}+\beta_{5} N P L_{i t}+\varepsilon_{i t} \\
& C R_{i t}=\beta_{0}+\beta_{1} C A R_{i t}+\beta_{2} B P R_{i t}+\beta_{3} G D P_{i t}+\beta_{4} N I M_{i t}+\varepsilon_{i t} \\
& N P L_{i t}=\beta_{0}+\beta_{1} C A R_{i t}+\beta_{2} B P R_{i t}+\beta_{3} C R_{i t}+\beta_{4} F E E S_{i t}+\varepsilon_{i t}
\end{aligned}
$$

Where NIM $_{i t}$ is net interest margin, CAR $_{\text {it }}$ is capital adequacy ratio, $\mathrm{BPR}_{\mathrm{it}}$ is Bank policy rate, CRit is credit growth, FEES it $_{\text {it }}$ fees charged by the banks, $\mathrm{NPL}_{\mathrm{it}}$ is non-performing loans and $\mathrm{GDP}_{\mathrm{it}}$ is a gross domestic product.

3 Formally Karachi Stock Exchange (KSE)

4 GDP growth (annual \%) - Pakistan. (n.d.). World Bank Open Data| Data. https://data.worldbank. org/indicator/NY.GDP.MKTP.KD.ZG?locations $=$ PK

5 countryeconomy.com. 2020. Pakistan - Key Rates 2020. [online] Available at: $<$ https:// countryeconomy.com/key-rates/pakistan> [Accessed 28 November 2020]. 


\section{Regulatory Capital $\left(\mathrm{CAR}_{\mathrm{it}}\right)$ and Efficiency $\left(\mathrm{NIM}_{\mathrm{it}}\right)$}

Based on equation 1, the impact of regulatory capital on efficiency was estimated by using NIMit (Net interest margin of the bank at time t.) NIM was considered as the dependent variable. NIMit was measured as the ratio of the difference between interest income and interest expenditure to total earning assets. It is also named as interest rate spread. NIMit was preferred over other indicators of efficiency due to its usage in the policy indicator, simplicity and availability of the data. We expected a positive relationship between NIMit and CARit as the high regulatory capital might raise the cost of equity funds, which ultimately increases lending rates. Despite efficiency purposes, higher interest rate spread also creates a buffer in terms of loan loss provisioning and by charging risk premium in lending to risky borrowers.

\section{Regulatory capital $\left(\mathrm{CAR}_{\mathrm{it}}\right)$ and Credit Growth $\left(\mathrm{CR}_{\mathrm{it}}\right)$}

Credit Growth is the gross advances of the bank in year t. Total outstanding advances show the risk profile of the banks (Taktak et al., 2010). CARit was expected to have a positive relationship with credit, as banks are likely to extend more loans when they have excess reserves. Further, banks also make few loans due to the trepidation created by the NPLs. Therefore, a negative relationship was expected between CR and NPL (Osei-Assibey $\&$ Asenso, 2015). Whereas, on the other side banks make more loans when NIM is on the higher side (Osei-Assibey \& Asenso, 2015). Therefore, we expected a positive relationship between NIM and CR.

\section{Regulatory Capital $\left(C A R_{i t}\right)$ and Non-Performing Loans (NPL $\left.L_{i t}\right)$}

NPL is the ratio of non-performing loans to total gross advances of the bank in year t. Total outstanding loans show the risk profile of the banks (Taktak et al., 2010). This shows the quality of bank loans, which is considered as a risk-taking incentive for the bank. We expected a negative relationship between NPL and CAR as the latter variable reduces nonperforming loans due to the maintenance of enough capital to mitigate the risk of default and bad loans (Alexandri \& Santoso, 2015).

We expected a positive relationship between CAR and NPL as the tendency of banks to extend loans is on the higher side when capital holdings are also on the higher side, which also tempts them to extend non-performing 
loans. A bank might take more risk to generate a return for depositors, who are the providers of the capital. Further, we also expected a positive relationship between NIM and NPL as wide interest rate spreads and higher lending rates also result in increased risk exposures, which give rise to financial distress by compromising stringent risk mitigation strategies. This gives rise to non-performing loans. Therefore, we also expected a positive relationship between CR and NPL (Adzis et al., 2010, Dushku et al., 2016; Sulong \& Mohd Noor, 2018).

\section{Bank Specific Control Variables}

$F E E_{i t}=$ This study also included bank-specific variables including fees and commissions for rendering services, it is the non-markup income of the bank $i$ in year $t$ is used in the literature as a proxy. Non-performing loans of banks increases when the fees charged by the banks are on the higher side. As the fees increase the incentive for banks to lend more to the borrowers with the expectation to increase income, whereas other things are held constant. Therefore, we expected a positive relationship between FEE and NPL (Osei-Assibey \& Asenso, 2015).

\section{Controlling for Macro-Economic Variables}

Macroeconomic variables included Bank Policy Rate (BPR) and Gross Domestic Product (GDP). Their detail is as under:

$G D P_{i t}=$ The rate of growth of the gross domestic product in year $t$ was used in the literature to proxy the business cycle. We expected a positive relationship between GDP and CR.

$B P R_{i t}=$ Bank policy rate is used by central banks for extending loans to commercial banks. The policy rate has short as well as long-term implications on NIM. We expected a positive relationship between BPR and NIM. This is also supported by an earlier study in the long run (Busch \& Memmel, 2015). Whereas, BPR has a negative relationship with CR because the former is the borrowing cost for the banks. Whereas, higher BPR persuades banks to extend more loans at a higher cost to borrowers, which ultimately increases the probability of non-performing loans. Therefore, we expected a positive relationship between BPR and NPL. This is also supported by an earlier study (Osei-Assibey \& Asenso, 2015). 


\section{Estimation Strategy}

We employed panel regression to examine the impact of regulatory capital adequacy ratio on efficiency, credit allocation, non-performing loans while controlling for bank-specific variables like fees and industry and macroeconomic variables including BPR and GDP. The data of the banks was a balanced panel. Due to the cross-sectional nature of data and endogeneity problem panel regression was used. Panel regression was employed to correct for the potential correlation of endogenous explanatory variables. Panel regression models including OLS, fixed and random effects under robust title were applied in this study to capture the impact of capital adequacy ratio on efficiency, credit growth and non-performing loans. The study estimated a linear regression model through OLS with some modification that was based on (Osei-Assibey \& Asenso, 2015).

\section{EMPIRICAL RESULTS}

\section{Descriptive Statistics}

The descriptive statistics of the key variables were estimated. It reports descriptive statistics of the dependent and independent variables. Descriptive statistics include the mean, median, maximum, minimum, standard deviation, Skewness and Kurtosis of the variables of twenty-one banks listed on the Pakistan Stock Exchange from the year 2010 to 2019.

Table 1: Descriptive Statistics of The Variables

(In Percentage Except For CR and FEES)

\begin{tabular}{lcccccccc}
\hline Variables & Mean & Median & Max & Mini & Std. Dev. & Skew & Kurt & Obs \\
\hline NIM & 0.030 & 0.030 & 0.068 & -0.003 & 0.011 & 0.152 & 4.290 & 208 \\
CR & 248.000 & 169.000 & 1150.000 & 6.536 & 239.000 & 1.495 & 5.167 & 208 \\
FEES & 7.335 & 4.594 & 36.249 & -0.668 & 7.936 & 1.734 & 5.664 & 208 \\
BPR & 10.931 & 9.880 & 20.250 & 5.880 & 4.037 & 0.913 & 3.392 & 208 \\
CAR & 16.522 & 14.825 & 53.900 & 1.080 & 8.202 & 2.247 & 9.314 & 208 \\
GDP & 3.979 & 4.675 & 5.830 & 0.989 & 1.602 & -0.643 & 2.092 & 208 \\
NPL & 0.117 & 0.100 & 0.516 & 0.000 & 0.085 & 1.947 & 8.238 & 208 \\
\hline
\end{tabular}


Table 1 exhibits descriptive statistics of the variables used in this study. Annual observations of banks listed on PSX were utilized for 2010-2019. The dependent variable included: Net Interest Margin (NIM), Credit Growth (CR) and Non-Performing Loans (NPL). Whereas, Bank Policy Rate (BPR), Capital Adequacy Ratio (CAR), Fees (FEES) and Gross Domestic Product (GDP) were independent variables.

Table 1 shows the descriptive statistics for all the variables used in the estimation of this study. The mean ratio of NIM was $3.00 \%$ with a maximum of $6.8 \%$ and a minimum of $-3.00 \%$. The standard deviation of NIM was $1.1 \%$, which represents the differences in NIM of different banks including public and private. The mean ratio of CR was $248 \mathrm{M}$ with a maximum of $1150 \mathrm{M}$ and a minimum of $6.5 \mathrm{M}$, which represented advances being extended by the banks. The standard deviation of CR was 239M which showed the differences in gross advances among the commercial banks' sample used in this study. The mean of FEES 7.3 M, with a maximum of $36.2 \mathrm{M}$ and a minimum of $-0.67 \mathrm{M}$ with a standard deviation of $7.9 \mathrm{M}$. The mean of BPR was $10.9 \%$ with a maximum of $20.2 \%$ and a minimum of $5.8 \%$ with a standard deviation of $4.03 \%$. The mean of CAR was $16.5 \%$ with a maximum of $53.9 \%$ and a minimum of $1.1 \%$ with a standard deviation of $8.2 \%$. The mean GDP is $3.9 \%$ with a maximum of $5.8 \%$ and a minimum of $0.9 \%$. The standard deviation of GDP was $1.6 \%$. The mean of NPL was $0.1 \%$ with a maximum of $0.5 \%$ and a minimum of zero percent with a standard deviation of $0.1 \%$.

\section{Correlation Matrix}

Correlation analysis was conducted to find the relationship between the independent variables. The correlation matrix shows all the independent variables including bank policy rate, capital adequacy ratio, credit growth, fees, gross domestic product, net interest margin and non-performing loans.

Table 2: Correlation Matrix

\begin{tabular}{lrrrrrrr}
\hline & \multicolumn{1}{c}{ BPR } & \multicolumn{1}{c}{ CAR } & CR & FEES & GDP & NIM & NPL \\
\hline BPR & 1 & $0.0418)$ & $(0.2281)$ & $(0.1388)$ & $(0.4994)$ & 0.1835 & 0.2106 \\
CAR & $(0.0418)$ & 1 & $(0.1192)$ & $(0.0773)$ & 0.0215 & 0.3100 & $(0.1470)$ \\
CR & $(0.2281)$ & $0.1192)$ & 1 & 0.8996 & 0.0445 & 0.1631 & $(0.2233)$ \\
FEES & $(0.1388)$ & $0.0773)$ & 0.7996 & 1 & 0.0945 & 0.2207 & $(0.1237)$
\end{tabular}




\begin{tabular}{crrrrrrr} 
GDP & $(0.4994)$ & 0.0215 & 0.0445 & 0.0945 & 1 & $(0.1434)$ & $(0.1472)$ \\
NIM & 0.1835 & 0.3100 & 0.1631 & 0.2207 & $(0.1434)$ & 1 & $(0.3845)$ \\
NPL & 0.2106 & $0.1470)$ & $(0.2233)$ & $(0.1237)$ & $(0.1472)$ & $(0.3845)$ & 1 \\
\hline \multicolumn{7}{l}{ The correlation table shows p-values with negative relationships are in parenthesis. }
\end{tabular}

Table 2 exhibits the results of capital adequacy ratio and efficiency, credit growth and non-performing loans in the sample of Pakistani commercial banks listed on the PSX for the years 2010 to 2019. The results of the correlation matrix showed that regression did not suffer from serious multicollinearity problems as mostly explanatory variables in the correlation matrix did not highly correlate with each other. The coefficient of CAR and NIM was positive which affirmed that the capital adequacy ratio increased efficiency in terms of net interest margin. Further, CR also had a positive relationship with CAR, which also revealed that capital adequacy regulations increased credit growth. The coefficient of CAR and NPL was negative, which also showed that stringent capital adequacy ratios also reduced nonperforming loans. The coefficient of CAR and GDP was positive which also showed that the capital adequacy ratio positively impacted the gross domestic product of the country. Whereas, CAR had a negative relationship with FEES and commissions.

\section{Regression Results}

Panel regression estimation technique was used in all three equations due to dual reasons: Firstly, due to the cross-sectional nature of data. Secondly, to address the possible endogeneity problem in data. The results of three separate equations including regulatory capital and interest margin, regulatory capital and credit growth, regulatory capital and non-performing loans are given below:

\section{Regulatory Capital and Net Interest Margin (NIM)}

The results of equation (1) of the relationship between regulatory capital and net interest margin along with control variables are given below: 
Table 3: Regulatory Capital and Net Interest Margin

\begin{tabular}{|c|c|c|}
\hline Variables & Signs & Fixed Effect \\
\hline Constant & & $\begin{array}{c}0.0323 \\
(0.0000)^{\star * *}\end{array}$ \\
\hline CAR & $+/-$ & $\begin{array}{c}0.0004 \\
(0.0000)^{* * *}\end{array}$ \\
\hline BPR & $+/-$ & $\begin{array}{c}0.0003 \\
(\mathbf{0 . 0 1 8 1})^{* *}\end{array}$ \\
\hline $\mathrm{CR}$ & + & $\begin{array}{c}-1.5600 \\
(0.0047)^{\star *}\end{array}$ \\
\hline FEES & - & $\begin{array}{c}-0.5830 \\
(\mathbf{0 . 0 0 2 7})^{\star *}\end{array}$ \\
\hline NPL & $+/-$ & $\begin{array}{c}-0.0374 \\
(\mathbf{0 . 0 0 0 0})^{\star * *}\end{array}$ \\
\hline Adjusted R-squared & & 0.6777 \\
\hline F-statistic & & 18.4146 \\
\hline
\end{tabular}

Hausman Test $\mathrm{X} 2(0.000)$

*** Statistical significance at the $1 \%,{ }^{* *}$ Statistical significance at the $5 \%$ level, ${ }^{*}$ Statistical significance at the $10 \%$ level. Fixed effect results are presented in Colum 3. The dependent variable includes NIM and independent variables are CAR, BPR, CR, FEES and NPL.

The Hausman test was employed to retain the results of fixed or random effect. The Hausman test suggest $\left(\chi^{2=5}, p\right.$-value $\left.=(0.000)\right)$, where the $p$-value was significant. Therefore, we retained the results of the fixed effect. The fixed effect results are shown in Table 3. Whereas, OLS and random effect results are shown in the Appendix 1. CAR revealed a positive and significant relationship with NIM at the $1 \%$ significance level, which showed that an increase in capital adequacy ratio increases NIM. The results are in line with an earlier study, which also indicated that well-capitalized banks are more efficient as compared to banks with less capital (Kwan \& Eisenbeis, 1997). Further, the findings of this study are consistent with the results of Hafez (2018) and Osei-Assibey and Asenso (2015). This supports the hypothesis that a stringent capital adequacy ratio has a positive impact on efficiency.

BPR has been included to learn more about its impact on NIM, as the banks use this rate for reference purposes while setting their base rates. BPR also had a positive and significant relationship with NIM at the 1\% significant level, which demonstrated that an increase in bank policy rate results in better interest spread for banks as they respond to BPR by tailoring 
their lending rates as well as by reducing their expenditures. The results of the study are in accordance with the research of Busch and Memmel (2015). Therefore, the result supports the hypothesis that there is a positive relationship between BPR and NIM.

Credit Growth was included to study its impact on net interest margin. CR had a negative relationship with NIM. Due to the trepidation created by the NPL, CR decreased with the increase in NIM. The results of this study also showed a negative relationship between CR and NIM at the 5\% significance level. FEE was used as the bank-specific control variable to study its impact on bank interest rate spread. It had a negative and significant relationship with NIM at the 5\% significant level. The results are counterintuitive as normally, it has a positive effect on NIM. Whereas, the findings of this study are consistent with the results of Putra et al. (2020). NPL measures the probability of bank default. As expected, there was a negative and significant relation between NPL and NIM at the $10 \%$ significant level which showed that bad loans decreased the interest rate spread of banks.

Therefore, the overall estimations demonstrate that stringent regulatory capital requirements and bank policy rate had a positive impact on bank interest rate spread in Pakistani commercial banks, which means that higher capital requirement would widen the bank spread between lending and saving rates. Further, another probable reason for this is the high cost of raising the capital, which they transfer to the consumers by increasing the lending rates. Whereas, CR, FEES and NPL had a negative impact on NIM. One plausible reason for high NPL and reduction in CR is high BPR and imposition of binding CAR. Higher credit risks and subsequent capital buffers might result in credit apprehensions and reduce credit expansions, which reduce NIM. Moreover, wider NIM also exacerbates NPL.

\section{Regulatory Capital and Credit Growth (CR)}

The results of equation (2) of the relationship between regulatory capital and credit growth along with control variables are given below: 
Table 4: Regulatory Capital and Credit Growth

\begin{tabular}{lcc} 
Variables & Signs & Fixed Effect \\
\hline Constant & & 5.4000 \\
CAR & $+/-$ & $\left(\mathbf{0 . 0 0 0 0 ) ^ { * * * }}\right.$ \\
& & 2.1101 \\
BPR & $+/-$ & $(\mathbf{0 . 1 6 1 9})^{* *}$ \\
& & -14.5806 \\
GDP & $+/-$ & $(\mathbf{0 . 0 0 0 0})^{* * *}$ \\
& & -13.9160 \\
NIM & $+/-$ & $(0.0023)^{* *}$ \\
& & -3.7200 \\
\hline Adjusted R-squared & & $(\mathbf{0 . 0 0 0 2})^{* *}$ \\
F-statistic & & 0.8593 \\
\hline Hausman Test X2 & & 53.6818 \\
\hline
\end{tabular}

***Statistical significance at the $1 \%$, ${ }^{*}$ Statistical significance at the $5 \%$ level, * Statistical significance at the $10 \%$ level. The dependent variable includes CR and independent variables are CAR, BPR, GDP \& NIM.

The Hausman test was employed to retain the results of fixed or random effect. The Hausman test suggest $\left(\chi^{2=4}, p\right.$-value $\left.=(0.0333)\right)$, where the p-value was significant. Therefore, we retained the results of the fixed effect and are shown in Table 4. Whereas, OLS and random effect results are shown in the Appendix 2. CAR revealed a positive but insignificant relationship with $\mathrm{CR}$ at the 5\% significance level. An increase in CAR resulted in an increase in credit growth. The results are in concord with the expectation that banks are likely to extend more loans when they have excess reserves (Osei-Assibey \& Asenso, 2015; Dao \& Nguyen, 2020). Generally, banks create an excess capital buffer and advance credit.

BPR has been included to learn more about its impact on credit growth as the banks use this rate for reference purpose while setting their base rates. BPR had a negative and significant relationship with NIM at the 1\% significant level, which demonstrated that an increase in bank policy rate results in a reduction in credit growth because of an increase in borrowing cost for the bank, which restricts the availability of loans for consumers. The results are in line with the expectation that banks are likely to extend fewer loans when the bank policy rate is on the higher side. 
Lastly, GDP and NIM had a negative and significant relationship with the $\mathrm{CR}$ at the $5 \%$ significance level, which is not in line with the expectation. Therefore, the overall estimations demonstrated that an increase in CAR increases credit growth. Whereas, BPR, GDP and NIM decreased credit growth.

\section{Regulatory Capital and Non-Performing Loans (NPL)}

The results of equation (3) of the relationship between regulatory capital and non-performing loans along with control variables are given below:

Table 5: Regulatory Capital and Non-Performing Loans

\begin{tabular}{lcc}
\multicolumn{1}{c}{ Variables } & Signs & Random Effect \\
\hline Constant & & 0.1093 \\
CAR & $+/-$ & $(\mathbf{0 . 0 0 0 1})^{* * *}$ \\
& & -0.0003 \\
BPR & $+/-$ & $(\mathbf{0 . 6 6 2 7})^{*}$ \\
& & 0.0030 \\
CR & $+/-$ & $(\mathbf{0 . 0 0 8 0})^{* *}$ \\
& & -1.3700 \\
FEES & $+/-$ & $(0.0055)^{* *}$ \\
& & 1.9300 \\
\hline Adjusted R-squared & & $(\mathbf{0 . 2 2 9 9})^{\star *}$ \\
F-statistic & & 0.1027 \\
\hline Hausman Test $X^{2=4}$ & & 6.9291 \\
\hline
\end{tabular}

*** Statistical significance at the $1 \%,{ }^{* *}$ Statistical significance at the $5 \%$ level, ${ }^{*}$ Statistical significance at the $10 \%$ level. The dependent variable includes NPL and independent variables are CAR, BPR, CR and FEES.

Table 5 shows the results of the random effect. Further, the Hausman test was employed to retain the results of fixed or random effect. The Hausman test suggest $\left(\chi^{2=4}, p\right.$-value $\left.=(0.4964)\right)$, where $p$-value was not significant. Therefore, we retained the results of the random effect. Whereas, OLS and fixed effect results are shown in the Appendix 3. The capital adequacy ratio revealed a negative but insignificant relationship with NPL at the $10 \%$ significance level. An increase in capital adequacy ratio resulted 
in a decrease in NPL, which affirmed that CAR played a positive role in the reduction of business risks including non-performing loans. The results are in accordance with earlier research conducted by Abiodun et al. (2020) and Yulianti et al. (2018).

Whereas, BPR had a positive and significant relationship with NPL at the $5 \%$ significance level, which is contrary to expectations, which means that an increase in bank policy rate persuades banks to extend more loans at a higher cost to borrowers, which ultimately increases the probability of non-performing loans. The result is in line with earlier research (OseiAssibey \& Asenso, 2015).

Moreover, Fees has a positive but insignificant relationship with NPL at the $10 \%$ significance level. The same reasoning hold for fees, which suggests that bad loans of banks increase when the fees charged by the banks are on the higher side. As the fees increase the incentive for banks to lend more to e borrowers with the expectation to increase income, whereas other things are held constant. The result is in accordance with an earlier study (Osei-Assibey \& Asenso, 2015).

Whereas, CR had a negative and significant relationship with NPL at the $5 \%$ significance level. The result is under the expectation that banks extend a few loans due to the trepidation created by the NPLs. Moreover, the result is also supported by an earlier study (Osei-Assibey \& Asenso, 2015). Therefore, CAR decreased NPL, which affirmed that CAR played a positive role in the reduction of business risks including NPLs. Whereas, higher BPR persuaded banks to extend more loans at a higher cost to borrowers, which ultimately increased the probability of non-performing loans. Moreover, higher fees also increased non-performing loans as banks extend more risky loans due to high income. Whereas, on the other side banks extended few loans due to the trepidation created by the NPLs.

In summary, the overall estimations demonstrate that stringent regulatory capital requirements in the shape of capital adequacy ratio and bank policy rate had a positive impact on the bank interest rate spread in Pakistani commercial banks. Further, the capital adequacy ratio also increased credit growth. Whereas, credit growth decreased with an increase in the bank policy rate. Furthermore, the capital adequacy ratio decreased 
non-performing loans, which affirmed that CAR played a positive role in the reduction of business risks including NPLs.

\section{CONCLUSION AND RECOMMENDATIONS}

We studied the impact of stringent regulatory capital requirements and the central bank policy rates on bank-related outcomes on including net interest margin, credit growth and non-performing loans in commercial banks listed on the Pakistan Stock Exchange from 2010 to 2019. We modeled three equations to study the impact and further applied the regression model. Hausman test was also applied and the results of fixed effect were retained for Net interest margin and credit growth. Whereas, random effect results were retained for non-performing loans.

Overall, the implementation of a stringent capital adequacy ratio increased the interest margin and credit growth in Pakistani commercial banks. Moreover, the capital adequacy ratio played a positive role in the reduction of non-performing loans. In specific, the overall estimations demonstrated that stringent regulatory capital requirements in the shape of capital adequacy ratio and bank policy rate have a positive impact on bank interest rate spread in Pakistani commercial banks. The results revealed that higher CAR increased the spread between lending and borrowing rate. Further, another probable reason for this was the high cost of raising the capital, which they transferred to the consumer by increasing the lending rates. Whereas, Credit, Fees and non-performing loans had a negative impact on net interest margin. One plausible reason for high non-performing loans and reduction in credit growth is the high bank policy rate and imposition of binding capital adequacy ratios. Higher credit risks and subsequent capital buffers might result in credit apprehensions and reduce credit expansions, which reduced the net interest margin. Moreover, a wider net interest margin also exacerbated non-performing loans.

Further, the overall estimations demonstrated that an increase in capital adequacy ratio increased credit growth. Whereas, bank policy rate, gross domestic product and net interest margin decreased credit growth. We found evidence in support that a higher capital adequacy ratio increased the credit growth in commercial banks in Pakistan, which indulged banks in 
risk-taking activities and gave rise to non-performing loans and reduction in net interest margin.

The results also revealed that the capital adequacy ratio decreased non-performing loans which affirmed that the capital adequacy ratio played a positive role in the reduction of business risks including NPLs. Whereas, a higher bank policy rate persuades banks to extend more loans at a higher cost to borrowers, which ultimately increased the probability of non-performing loans. Moreover, higher fees also increased non-performing loans as banks extended more risky loans due to high income. Thereafter, as a result, banks extended a few loans due to the trepidation created by the NPLs.

This study helps regulators in customizing their regulations on credit growth to reduce non-performing loans and maintain a healthy growth of loans by not compromising on interest margins as well as maintenance of minimum capital adequacy ratios. The results also assist economists to assess the overall effect of implementing a regulatory capital requirement for the banking sector as well as the economy. Further, this study also provides evidence to banks and financial institutions in assessing the implication of maintaining regulatory capital adequacy ratios to avoid bankruptcy.

\section{REFERENCES}

Abbas, F., Butt, S., Masood, O., \& Javaria, K. (2019). The effect of bank capital buffer on bank risk and net interest margin: Evidence from the US. Global Journal of Social Sciences Studies, 5(2), 72-87.

Abiodun, S. W., Abdul-Azeez, A. A., \& Adewale, Y. L. (2020). Determinants of capital adequacy of Nigerian banks. Market Forces, 15(1), 1-15.

Adzis, A., Tripe, D., \& Dunmore, P. (2010). International Financial Reporting Standards (IFRS) and income smoothing activities of banks: Evidence from Australia and New Zealand commercial banks. In Finance and Corporate Governance Conference.

Alexandri, M. B., \& Santoso, T. I. (2015). Non-performing loan: Impact of internal and external factors (Evidence in Indonesia). International Journal of Humanities and Social Science Invention, 4(1), 87-91. 
Bernanke, B. S., Lown, C. S., \& Friedman, B. M. (1991). The credit crunch. Brookings Papers on Economic Activity, 1991(2), 205-247.

Taktak, N. B., Ben Slama Zouari, S., \& Boudriga, A. (2010). Do Islamic banks use loan loss provisions to smooth their results? Journal of Islamic Accounting and Business Research, 1(2), 114-127.

Busch, R., \& Memmel, C. (2015). Banks'net interest margin and the level of interest rates (Deutsche Bundesbank Discussion Paper No 16/2015). Retrieved from https://www.bundesbank.de/resource/blob/703920/7 e9b77f93f661f95f6b9535e5151679c/mL/2015-07-14-dkp-16-data.pdf

Carlson, M., Shan, H., \& Warusawitharana, M. (2013). Capital ratios and bank lending: A matched bank approach. Journal of Financial Intermediation, 22(4), 663-687.

Cornett, M. M., McNutt, J. J., Strahan, P. E., \& Tehranian, H. (2011). Liquidity risk management and credit supply in the financial crisis. Journal of Financial Economics, 101(2), 297-312.

Cruz-García, P., \& Fernandez de Guevara, J. (2020). Determinants of net interest margin: The effect of capital requirements and deposit insurance scheme. The European Journal of Finance, 26(11), 1102-1123.

Dao, B. T. T., \& Nguyen, K. A. (2020). Bank capital adequacy ratio and bank performance in Vietnam: A simultaneous equations framework. The Journal of Asian Finance, Economics, and Business, 7(6), 39-46.

Dushku, E. (2016). Some empirical evidence of loan loss provisions for Albanian banks. Journal of Central Banking Theory and Practice, 5(2), 157-173.

El-Ansary, O., \& Hafez, H. (2015). Determinants of capital adequacy ratio: An empirical study on Egyptian banks. Corporate Ownership \& Control, 13(1), 806-816.

Gul, S., Irshad, F., \& Zaman, K. (2011). Factors affecting bank profitability in Pakistan. Romanian Economic Journal, 14(39), 61-85. 
Hafez, M. (2018). Examining the relationship between efficiency and capital adequacy ratio: Islamic versus conventional banks - An empirical evidence on Egyptian Banks. Accounting and Finance Research, 7(2), 232-247.

Haris, M., Tan, Y., Malik, A., \& Ain, Q. U. (2020). A study on the impact of capitalization on the profitability of banks in emerging markets: A case of Pakistan. Journal of Risk and Financial Management, 13(9), 217.

Karim, M. A., Hassan, M. K., Hassan, T., \& Mohamad, S. (2014). Capital adequacy and lending and deposit behaviors of conventional and Islamic banks. Pacific-Basin Finance Journal, 28, 58-75.

Kupiec, P., Lee, Y., \& Rosenfeld, C. (2017). Does bank supervision impact bank loan growth? Journal of Financial Stability, 28, 29-48.

Kwan, S., \& Eisenbeis, R. A. (1997). Bank risk, capitalization, and operating efficiency. Journal of Financial Services Research, 12(2-3), 117-131.

Osei-Assibey, E., \& Asenso, J. K. (2015). Regulatory capital and its effect on credit growth, non-performing loans and bank efficiency. Journal of Financial Economic Policy, 7(4), 401-420.

Pasiouras, F., Tanna, S., \& Zopounidis, C. (2009). The impact of banking regulations on banks' cost and profit efficiency: Cross-country evidence. International Review of Financial Analysis, 18(5), 294-302.

Putra, F. A., Hakim, D. B., \& Tambunan, M. E. (2020). Determinant analysis of net interest margin and banking profitability in Indonesia. International Journal of Science and Research (IJSR), 9(1), 174-180.

Rafique, Z. Z., Toor, K. N., \& Bashir, Z. (2020). Capital adequacy and management quality for banking liquidity management decision in Pakistan. KASBIT Business Journal (KBJ), 13(1), 25-42.

Sulong, Z. \& Mohd Noor, S. N. (2018). Distribution of depositors' return and the income smoothing hypothesis by Malaysian Islamic banks. Global Journal Al-Thaqafah, 171-187. 
Waqas, H., \& Bahrain, S. (2019). Risk management, capital adequacy and audit quality for financial stability: Assessment from commercial banks of Pakistan. Asian Economic and Financial Review, 9(6), 654-664.

Yulianti, E., Aliamin, A., \& Ibrahim, R. (2018). The effect of capital adequacy and bank size on non-performing loans in Indonesian public banks. Journal of Accounting Research, Organization and Economics, 1(2), 205-214.

Zhang, D., Cai, J., Dickinson, D. G., \& Kutan, A. M. (2016). Non-performing loans, moral hazard and regulation of the Chinese commercial banking system. Journal of Banking \& Finance, 63, 48-60. 


\section{APPENDIXES}

\section{Appendix 1: Regulatory Capital and Net Interest Margin}

\begin{tabular}{lccc}
\multicolumn{1}{c}{ Variables } & Signs & OLS & Random Effect \\
\hline Constant & & 0.02088 & 0.02453 \\
& & $(\mathbf{0 . 0 0 0 0})^{* * *}$ & $(\mathbf{0 . 0 0 0 0})^{* * *}$ \\
CAR & $+/-$ & 0.00033 & 0.00038 \\
& & $(\mathbf{0 . 0 0 0 0})^{* * *}$ & $(\mathbf{0 . 0 0 0 0})^{* * *}$ \\
BPR & $+/-$ & 0.00069 & 0.0006 \\
& & $(\mathbf{0 . 0 0 0 0})^{* * *}$ & $(\mathbf{0 . 0 0 0 0})^{* * *}$ \\
CR & + & -3.0600 & -8.5300 \\
& & $(\mathbf{0 . 5 5 0 0})^{*}$ & $(0.1004)^{* *}$ \\
FEES & - & 3.6000 & -5.0100 \\
& & $\mathbf{( 0 . 0 2 0 9})^{* *}$ & $(0.7643)^{*}$ \\
NPL & $+/-$ & -0.05619 & -0.0381 \\
& & $(\mathbf{0 . 0 0 0 0})^{* * *}$ & $(\mathbf{0 . 0 0 0 0})^{* * *}$ \\
\hline Adjusted R-squared & & 0.4272 & 0.2179 \\
F-statistic & 31.8790 & 12.5352 \\
\hline Hausman Test X2 & & $5(0.000)$ &
\end{tabular}

***Statistical significance at the $1 \%,{ }^{* *}$ Statistical significance at the $5 \%$ level, ${ }^{*}$ Statistical significance at the $10 \%$ level. The dependent variable includes NIM and independent variables are CAR, BPR, CR, FEES and NPL.

\section{Appendix 2: Regulatory Capital and Credit Growth}

\begin{tabular}{|c|c|c|c|}
\hline Variables & Signs & OLS & Random Effect \\
\hline Constant & & $\begin{array}{c}3.7600 \\
(\mathbf{0 . 0 0 0 0})^{\star * *}\end{array}$ & $\begin{array}{c}5.3400 \\
(\mathbf{0 . 0 0 0 0})^{* * *}\end{array}$ \\
\hline CAR & $+/-$ & $\begin{array}{c}-6.7106 \\
(\mathbf{0 . 0 0 0 0})^{\star * *}\end{array}$ & $\begin{array}{c}1.6269 \\
(\mathbf{0 . 2 6 8 2})^{\star *}\end{array}$ \\
\hline BPR & $+/-$ & $\begin{array}{c}-1.7279 \\
(\mathbf{0 . 0 0 0 0})^{\star * *}\end{array}$ & $\begin{array}{c}-14.8082 \\
(\mathbf{0 . 0 0 0 0})^{* * *}\end{array}$ \\
\hline GDP & $+/-$ & $\begin{array}{c}-1.0759 \\
(\mathbf{0 . 0 6 4 4})^{\star}\end{array}$ & $\begin{array}{c}-13.7408 \\
(0.0026)^{* *}\end{array}$ \\
\hline NIM & $+/-$ & $\begin{array}{c}5.8000 \\
(\mathbf{0 . 0 0 0 0})^{\star * *}\end{array}$ & $\begin{array}{c}-3.2500 \\
(0.0007)^{\star \star *}\end{array}$ \\
\hline Adjusted R-squared & & 0.3038 & 0.3073 \\
\hline F-statistic & & 23.5839 & 23.9659 \\
\hline Hausman Test $x 2$ & & $4(0.0333)$ & \\
\hline
\end{tabular}

${ }^{* * *}$ Statistical significance at the $1 \%,{ }^{* *}$ Statistical significance at the $5 \%$ level, ${ }^{*}$ Statistical significance at the $10 \%$ level. The dependent variable includes CR and independent variables are CAR, BPR, GDP, and NIM. 


\section{Appendix 3: Regulatory Capital and Non-Performing Loans}

\begin{tabular}{|c|c|c|c|}
\hline Variables & Signs & OLS & Fixed Effect \\
\hline Constant & & $\begin{array}{c}0.1101 \\
(\mathbf{0 . 0 0 0 0})^{* * *}\end{array}$ & $\begin{array}{c}0.1067 \\
(\mathbf{0 . 0 0 0 3})^{\star * *}\end{array}$ \\
\hline CAR & $+1-$ & $\begin{array}{c}-0.0012 \\
(\mathbf{0 . 0 1 1 8})^{* *}\end{array}$ & $\begin{array}{c}0.0001 \\
(\mathbf{0 . 8 4 3 0})^{*}\end{array}$ \\
\hline BPR & $+/-$ & $\begin{array}{c}0.0031 \\
(\mathbf{0 . 0 0 0 0})^{\star * *}\end{array}$ & $\begin{array}{c}0.0029 \\
(\mathbf{0 . 0 1 8 1})^{\star * *}\end{array}$ \\
\hline CR & $+/-$ & $\begin{array}{c}-1.0800 \\
(\mathbf{0 . 0 0 0 5})^{\star *}\end{array}$ & $\begin{array}{c}-1.3700 \\
(0.0087)^{\star \star \star}\end{array}$ \\
\hline FEES & $+/-$ & $\begin{array}{c}2.1000 \\
(\mathbf{0 . 0 1 3 4})^{\star * *}\end{array}$ & $\begin{array}{c}1.2100 \\
(\mathbf{0 . 5 1 2 4})^{*}\end{array}$ \\
\hline Adjusted R-squared & & 0.2166 & 0.5108 \\
\hline F-statistic & & 15.3092 & 10.0082 \\
\hline Hausman Test X2 & & $4(0.4964)$ & \\
\hline
\end{tabular}

